\title{
A politização das migrações internacionais: direitos humanos e soberania nacional
}

\author{
Fausto Brito*
}

O objetivo deste artigo é analisar a reação dos países desenvolvidos à imigração internacional através de uma legislação restritiva. Considera-se que a causa dessa reação não é exclusivamente conjuntural, derivada da crise contemporânea do capitalismo, mas reside na própria formação estrutural desses países receptores de imigrantes. O fundamento da análise política desenvolvida encontra-se na compreensão do paradoxo estabelecido entre a soberania de cada um dos países e a universalização dos direitos humanos, em especial dos imigrantes. Seguindo um itinerário semelhante ao de Hanna Arendt, a análise da politização das migrações internacionais acompanhará sua história a partir da segunda metade de século XIX até os dias atuais, enfatizando três grandes períodos: o anterior à Primeira Guerra Mundial, reconhecido como a era do imperialismo; o período entre as duas Grandes Guerras Mundiais; e o pós-guerra, contemplado, já no seu início, pela Declaração Universal dos Direitos Humanos de 1948.

Palavras-chave: Migração internacional. Direitos humanos. Soberania nacional.

\footnotetext{
* Professor e pesquisador do Centro de Desenvolvimento e Planejamento Regional (Cedeplar) e do Departamento de Demografia da Universidade Federal de Minas Gerais (fbrito@cedeplar.ufmg.br).
} 


\section{Introdução}

A reação de grande parte dos países desenvolvidos no que se refere à imigração internacional, por meio de uma rigorosa legislação visando seu controle, tem se constituído em um dos mais importantes problemas políticos contemporâneos. Contudo, considerando o envelhecimento da população desses países, hoje com taxas de fecundidade aquém do nível de reposição, a imigração tem sido necessária, pois a oferta de mão de obra nacional não satisfaz às necessidades da economia. Coloca-se, então, a seguinte questão: se a imigração é necessária, então qual a razão para uma legislação tão restritiva. ${ }^{1}$

Uma primeira resposta poderia atribuir à crise econômica de muitos países desenvolvidos, acompanhada de altas taxas de desemprego, o motivo da reação generalizada aos imigrantes. Não há dúvidas quanto às dificuldades derivadas da crise e de suas implicações na formulação das políticas anti-imigratórias. Entretanto, essa hipótese pode sugerir um caráter meramente conjuntural a essas reações, o que não parece um caminho analítico adequado.

A opção teórica deste artigo, ao contrário, é pensar essas reações à imigração internacional numa perspectiva histórica, mostrando que elas podem ser compreendidas como resultado da própria formação social e política dos países desenvolvidos. Não se trata de nenhuma adesão a uma filosofia da história que justifique qualquer forma de determinismo. A compreensão histórica não tem como propósito procurar uma cadeia de causas que tornem os eventos atuais resultados irreversíveis. O que se procura compreender é como alguns elementos encontrados na história dos países desenvolvidos, hoje cristalizados nas suas estruturas, contribuem para explicar as reações às imigrações internacionais.

A intensa politização das imigrações, ou seja, seu lugar cada vez mais proeminente na agenda política dos diferentes países receptores de imigrantes, tem mobilizado a opinião pública e os debates parlamentares, assumindo grande relevância nos programas partidários, em especial dos conservadores, em que o anti-imigracionismo tornou-se um elemento político decisivo. Esse confronto de interesses, traduzido na legislação cada vez mais desfavorável aos imigrantes, contém particularidades que se transformaram em objeto fascinante para a reflexão. Vale sublinhar que a politização, em graus diferentes, não é uma novidade histórica: as imigrações internacionais têm sido um tema político central no desenvolvimento do capitalismo desde a segunda metade do século XIX.

A análise política desenvolvida neste artigo tem como referência teórica mais importante a contribuição da filosofia política de Hannah Arendt. Suas análises, de fato, estão mais voltadas para o período entre o último quartel do século XIX e os anos imediatamente subsequentes à segunda Grande Guerra Mundial. Mas as dimensões heurísticas de seus conceitos e de sua filosofia política possibilitam sua utilização para outros períodos históricos, inclusive para os dias atuais.

\footnotetext{
1 Ainda que não seja o tema deste artigo, deve-se mencionar que as políticas restritivas coexistem, em muitos países desenvolvidos, com o estímulo à imigração de mão de obra qualificada originária de países emergentes como o Brasil.
} 
A compreensão de Arendt a respeito do grande deslocamento da população, resultante da desintegração europeia entre as duas guerras, revela a emergência de dois grandes grupos: os apátridas e as minorias. Os últimos eram parcialmente povos sem Estado, pois pertenciam ao corpo político, mas não estavam plenamente integrados à nação, necessitando, desse modo, de proteção e garantias internacionais concedidas pela Liga das Nações. Os apátridas eram, de fato, os verdadeiros povos sem Estado. Desnacionalizados pelos seus governos nos países de origem, e deles expulsos, não tinham cidadania reconhecida nos países de destino. Na perspectiva da proteção da lei, tratava-se de pessoas supérfluas, sem os direitos humanos reconhecidos desde as Revoluções Americana e Francesa.

Os apátridas e as minorias estabeleciam um problema fundamental para os direitos humanos consagrados desde a segunda metade do século XVIII, incorporados à tradição ocidental e considerados inerentes ao homem. Para Arendt, em face desses dois grupos, os direitos humanos passaram a ser reconhecidos somente como direitos dos nacionais. A soberania nacional se sobrepõe aos direitos humanos das minorias e dos apátridas, principalmente destes últimos. Eles são considerados uma população supérflua, sem os atributos que o direito e a política concediam aos nacionais.

Os imigrantes econômicos, também, já aparecem na cena histórica. São os que se deslocam entre os países em função das necessidades do mercado de trabalho e surgem como objeto de políticas restritivas impostas pelos governos, em especial o francês. Não é o caso clássico dos “displaced persons", mas nem por isso devem ser omitidos na análise do dilema entre direitos humanos e soberania nacional.

Os imigrantes internacionais, hoje, não são semelhantes às minorias ou aos apátridas, pois, em geral, mantêm a cidadania nos seus países de origem. Contudo, ao se deslocar para um país de destino, o migrante não leva consigo seus direitos garantidos no país onde nasceu. No mundo posterior à Segunda Grande Guerra ainda permanece a contradição entre a soberania nacional e os direitos humanos. Essa é a dimensão política fundamental das migrações internacionais e a razão básica da sua extrema politização nos dias atuais.

Hannah Arendt considera que a dissociação entre direitos humanos e soberania nacional serviu de antessala para a ruptura total dos direitos humanos nos regimes totalitários. A superação tanto do nazismo quanto do stalinismo, pela democracia liberal, não foi suficiente para eximir a história contemporânea de muitos dos seus traços. As ideologias raciais têm ressurgido em muitos países desenvolvidos e servem de pano de fundo para a descriminação étnica intrínseca às políticas de restrições às imigrações internacionais. O desrespeito à diversidade étnica caminha junto com o desrespeito aos direitos humanos, mais de 200 anos depois das Revoluções Americana e Francesa e mais de meio século após a Declaração Universal dos Direitos Humanos.

A questão fundamental na perspectiva arendtiana seria recuperar a tópica kantiana da "hospitalidade universal", deslocando-se do espaço da tríade Estado-Povo-Território para a compreensão da humanidade como fonte de direito. Os direitos humanos seriam fundamentados não na natureza humana, mas sim na própria humanidade à qual todos 
pertencem, sem restrições de nacionalidade. Pertencer à humanidade significa ter direito a ter direitos e ser humano seria a sua garantia efetiva.

Seguindo um itinerário semelhante ao de Arendt, a análise da politização das migrações internacionais acompanhará sua história a partir da segunda metade de século XIX até os dias atuais, enfatizando três grandes períodos: o anterior à Primeira Guerra Mundial, reconhecido como a era do imperialismo; o período entre as duas Grandes Guerras Mundiais; e o pós-guerra, contemplado, já no seu início, pela Declaração Universal dos Direitos Humanos de 1948.

\section{Ideologia racial e as políticas migratórias: a mobilidade internacional da população na segunda metade do século XIX e início do XX}

A partir da segunda metade do século XIX, as migrações internacionais já assumiam uma relevância notável. Se hoje se destacam os fluxos migratórios com origem nos países mais pobres e tendo por destino os países mais ricos, naquela época a direção dos fluxos era inversa. Da Europa partiram milhões de migrantes com o objetivo de liberar alguns países europeus de seu excedente demográfico, assim como para satisfazer às necessidades de ocupação demográfica de países como Estados Unidos, Canadá, Argentina, Brasil e Austrália (BRITO, 1995, p. 56).

A enorme redistribuição da população mundial só se tornou possível pelas possibilidades geradas pela grande reestruturação produtiva da economia capitalista e pela sua internacionalização comandada pelo capital financeiro. O notável crescimento econômico foi facilitado pela intensificação do progresso técnico, em particular nos meios de transportes. Essa fase da economia mundial, que vai do segundo quartel do século XIX até a primeira Grande Guerra Mundial, é chamada, por muitos historiadores, de a era do imperialismo (HOBSBAWN, 2003, p. 27).

Não só a população se expandia pelo mundo em direção às Américas e à Austrália, como também o capital avançava na direção da conquista dos continentes africano e asiático e do controle político da América Latina. As grandes potências europeias promoveram um novo colonialismo em que a conquista política quase sempre significaria, efetivamente, um controle territorial. A Ásia e África, principalmente, foram repartidas em colônias com o objetivo não da ocupação demográfica e da construção social, mas sim da subordinação pela força. As novas colônias eram fundamentais não só como mercado para os produtos e para o capital dos países centrais, mas também como fontes de bens primários, produtos agrícolas e minerais, indispensáveis à acumulação de capital nos países centrais.

As articulações econômicas, sociais e políticas do velho com o novo mundo, seja pela expansão demográfica ou pela conquista imperialista, abriram caminhos para as migrações e a internacionalização dos mercados. Ao mesmo tempo, a convivência de povos com etnias diferentes foi extremamente favorável para a emergência e consolidação política de doutrinas raciais que dividiam a humanidade entre raças dominantes ou superiores e raças inferiores que deveriam ser dominadas. O racismo foi incorporado à visão da política e da 
história, transformando-se numa das principais armas do imperialismo e, em muitos países, serviu como ideologia a orientar políticas de Estado (ARENDT, 2004, p. 189; FOUCAULT, 2005, p.199).

A origem do pensamento racista se deu na França bem antes da etapa das grandes migrações e do imperialismo. Já no século XVIII, o conde Boulanvillier (1658-1722) interpretava a história francesa como uma "guerra entre raças", ou como uma guerra entre duas etnias que, de fato, representavam duas nações diferentes. Para ele, os francos, de etnia germânica, haviam conquistado, pela força, depois da queda do Império Romano, o território que seria posteriormente considerado como a França. Ali habitavam os gauleses que perderam suas terras para a "aristocracia germânica", que se estabeleceu como classe governante, legitimando-se por meio do direito de conquista e exigindo a obediência devida ao mais forte. Para Boulanvillier, governar de acordo com os interesses da aristocracia significava ir além do próprio território, ultrapassando as fronteiras convencionais à procura de uma unidade internacional entre as aristocracias germânicas (ARENDT, 2004, p. 192).

Os franceses, portanto, antes dos próprios alemães, insistiram na ideia de superioridade germânica. A ideologia racista assumiu na Alemanha um papel diferente do que teve na França, sendo utilizada como um poderoso mecanismo político dentro do projeto de unificação nacional. O grande objetivo era unificar o povo de origem étnica comum germânica - sob um Estado-Nação, o que só aconteceria, de fato, na segunda metade do século XIX. Neste processo histórico, nacionalismo e racismo acabaram por se identificar (ARENDT, 2004, p. 195).

O pensador francês que realmente incorporou a raça como um fator decisivo na dinâmica da história foi o conde Arthur de Gobineau (1816-1882) em seu Essai sur l'inegalité des races humaines, publicado em 1855 . Ele acreditou na existência de uma lei natural que regeria a história humana e explicaria o declínio das civilizações: a degenerescência racial fruto das misturas de diferentes raças ou de "sangues". A preponderância da raça inferior nessa mistura levaria ao declínio das civilizações (ARENDT, 2004, p. 203).

Politicamente, o interesse de Gobineau era a criação de uma nova elite para substituir a aristocracia que corria o sério risco, na democracia liberal, de submergir diante das classes inferiores. Ele sugeria, então, a criação de uma "raça de príncipes”, os arianos, para fazer frente às classes inferiores que se expandiam. Essa nova elite racial seria um suporte político fundamental na luta não só contra a democracia, mas também contra o nacionalismo ou qualquer forma de patriotismo. Seguindo a tradição do pensamento racial francês, a nova "raça de príncipes" arianos não se continha nos estreitos limites do território de uma nação (ARENDT, 2004, p. 204).

Na Inglaterra, país à frente da expansão imperialista do século XIX, a ideologia racial trazia como mote a preponderância histórica do povo inglês, em que a hereditariedade se identificava com a supremacia racial. Benjamin Disraeli (1804-1881), político e escritor, dizia: "O inglês é o homem superior e a história da Inglaterra é a história de sua evolução" (apud ARENDT, 2004, p. 211). 
A maior expressão da ideologia racial inglesa foi o darwinismo social que relacionava a "sobrevivência dos mais aptos", na luta pela existência humana, com a eugenia, ou seja, com o melhoramento genético (ARENDT, 2004, p. 209). O contato europeu, inglês em particular, com os povos da África e da Ásia na expansão imperialista utilizava a ideologia da supremacia racial como o discurso necessário para justificar a superioridade da civilização europeia, afirmada pela dominação política e subordinação social e cultural dos povos colonizados.

A ideologia racial não era uma novidade histórica no século XIX, estando presente no chamado Antigo Sistema Colonial, contemporâneo da expansão marítima do século XVI, que se desdobrou até o início do século XIX. A escravidão dos indígenas, o seu genocídio generalizado e a destruição das suas civilizações abriram as portas para um dos negócios mais rentáveis para o capital mercantil que comandava o antigo sistema colonial: a escravidão negra. Os negros africanos eram comercializados nas colônias como mão de obra necessária às suas economias e muitas delas, como Brasil e Estados Unidos, mantiveram a escravidão mesmo depois da suas respectivas independências, ou seja, após quebrarem seus laços de coloniais.

Reduzidos à mera mercadoria, objetos negociados no mercado com preços estabelecidos e sujeitos às condições sub-humanas, os escravos eram o retrato vivo da ideologia da supremacia racial dos povos metropolitanos. Não há como entender a escravidão exclusivamente no plano econômico, em função dos seus lucros extraordinários, deixando de considerar a ideologia racista que a justificava. De fato, não era a força de trabalho dos negros que era comercializada, como no capitalismo, o que exigiria a existência da liberdade necessária, mesmo que negativa, mas sim o indivíduo como um todo, uma máquina de trabalho, destituído de toda a forma de liberdade. Esse objeto, cuja propriedade era transferida por meio do mercado, trazia previamente uma marca racial. Era escravo não só pelo seu valor no mercado, mas, principalmente, porque era negro (FOUCAULT, 2005, p. 307).

O século XIX, com o seu novo colonialismo, reinventou o racismo quando em muitos países ainda não tinha se encerrado a escravidão originária do antigo sistema colonial. 0 Brasil é um caso excelente dessa continuidade: a predominância da ideologia racista e sua efetivação como política de Estado ultrapassaram a fase colonial, penetrando no período imperial até a República. A dominação e extermínio da população indígena e a escravidão que atravessou quase três séculos foram eventos marcantes na história brasileira. Na segunda metade do século XIX, quando da iminência da abolição da escravatura, o Brasil incorporou a ideologia racista ao discurso necessário para justificar a imigração internacional como uma política de Estado.

O Estado nacional no Brasil, desde a sua origem, tinha como um dos seus fundamentos a política racial. Em primeiro lugar, a grande tradição de dominação e extinção dos povos indígenas sempre foi, desde a época colonial, uma efetiva política da metrópole. Em segundo lugar, era um Estado escravocrata e, portanto, por definição estabelecia uma hierarquia racial, reduzindo os negros à mera mercadoria e a uma posição socialmente subalterna. Em terceiro lugar, mesmo antes do debate da segunda metade do século XIX, já andava 
à procura de "gente branca e industriosa" para modificar a composição étnica do povo brasileiro. Escravidão e eugenia caminharam juntas no Brasil durante a colônia, o império e mesmo após a abolição da escravatura, deixando marcas profundas na sociedade brasileira que persistem até hoje.

Gobineau, já mencionado neste artigo, esteve no Brasil em 1869, como diplomata do governo francês de Napoleão III. Aqui ficou apenas um ano, mas tornou-se amigo de D. Pedro II, que the solicitou um trabalho sobre o Brasil para a Exposição Universal de Viena: Emigration aux Brésil: L'Empire du Brésil à l'Exposition Universelle de Vienne em 1873 (READERS, 1988, p. 215).

Nesse trabalho, ele tece considerações elogiosas sobre o país, como seria necessário a um documento escrito para o governo brasileiro, mas não deixa de traduzir para a realidade local as suas ideias sobre as relações raciais. Ele justifica as imigrações internacionais baseado no argumento de que a população brasileira teria sérios problemas de crescimento devido à situação dos mulatos, que não podiam se reproduzir além de um número limitado de gerações. Em seu texto encomendado pelo governo brasileiro, Gobineau escreveu:

Mas, se em vez de reproduzir entre si, a população brasileira estivesse em condições de subdividir mais ainda os elementos daninhos de sua atual constituição étnica, fortalecendo-se através de alianças de maior valor com as raças européias, o movimento de destruição observado em suas fileiras se encerraria dando lugar a uma ação contrária. A raça se restabeleceria, a saúde pública melhoraria, a índole moral se retemperararia e as mais felizes mudanças se introduziriam na situação social deste adorável país (READERS, 1988: p. 240).

Escravidão e políticas de melhoramento étnico, fortemente patrocinadas pelo Estado e com grande penetração entre as elites, tiveram como resultado colocar a questão racial entre os fundamentos da desigualdade social no Brasil (NABUCO, 2000, p. 154; VIANA, 2000, p. 1013). Os índios "preguiçosos" e os negros "servis", raças inferiores, estavam sujeitos, a priori, à exclusão social. Não só eles, mas grande parte da população brasileira, resultante da miscigenação dos negros e índios com os portugueses, com o seu gênio "autoritário e tacanho", também estava excluída (SKDMORE, 1976, p. 38).

A questão racial brasileira atravessou grupos específicos como os negros ou os índios e expôs a população resultante da miscigenação, principalmente a mais pobre, à discriminação social. Dissimulando a questão racial, difundiu-se pela sociedade brasileira a cultura do homem pobre, fruto da miscigenação, como um “caipira”, um "preguiçoso", um "indolente”, em síntese, alguém com pouca aptidão para o trabalho. Na transição para a economia capitalista no Brasil, isso significava um atestado de marginalização, pois nem a força de trabalho, a única propriedade dos mais pobres, tinha algum valor. Ao contrário dos imigrantes "brancos e industriosos" que deveriam suprir, segundo as elites, as necessidades do mercado de trabalho da economia cafeeira capitalista.

O caso brasileiro é um notável exemplo de implementação de políticas raciais pelo Estado, particularmente na promoção da imigração internacional, situando-se dentro do contexto 
internacional da segunda metade do século XIX. Um mundo onde a ideologia racial servia de suporte para a expansão econômica e política das grandes nações imperiais. 0 resultado dessa ideologia, no século XX, vai ser posto ao limite com as experiências totalitárias.

\section{Crises e conflitos: a emergência dos displaced persons entre as duas grandes guerras}

As migrações internacionais no período entre as duas Grandes Guerras sofreram um forte impacto dos conflitos militares e das crises econômicas e políticas que se iniciaram com a Revolução Russa de 1917 e expandiram-se pelas décadas de 1920 e 1930. Como seria de se esperar, neste contexto, o volume das migrações europeias para a América reduziu-se substancialmente. Todavia, em decorrência dessa mesma situação internacional, em particular da desintegração de diversos Estados nacionais europeus, emerge um tipo específico de mobilidade forçada da população do qual se destacam dois grandes grupos sociais: os apátridas e as minorias.

As minorias, oficialmente reconhecidas pelo Tratado de Paz decorrente do final da Primeira Grande Guerra Mundial, foram resultantes, no leste europeu, principalmente, da desintegração dos dois grandes impérios multinacionais: a Rússia czarista e a Áustria-Hungria (ARENDT, 2004, p. 301). Segundo Arendt, nos Estados sucessores, aproximadamente 30\% dos seus 100 milhões de habitantes eram oficialmente reconhecidos como sujeitos à proteção da Liga das Nações por meio do Tratado de Minorias. Entre eles, milhões de russos e alemães, centenas de milhares de armênios, romenos, húngaros e espanhóis (ARENDT, 2004, p. 305 e 311).

Os apátridas constituíam um caso político excepcional: perderam sua nacionalidade no Estado de origem e, obrigados a se deslocarem para outros países, não tinham os seus direitos mínimos de cidadãos reconhecidos no lugar de destino (ARENDT, 2004, p. 313). Estes expulsos da clássica trindade Estado-Povo-Território haviam perdido aqueles direitos que, desde as Revoluções Americana e Francesa, "eram tidos e até definidos como inalienáveis, ou seja, os Direitos do Homem” (ARENDT, 2004, p. 301). Os apátridas, antes restritos ao leste europeu, entre as duas Grandes Guerras, espalhavam-se por toda a Europa. As estatísticas sobre o seu número não eram dignas de confiança: oficialmente reconhecia-se cerca de um milhão de apátridas, mas estimava-se em mais de dez milhões. Somente na França, antes da Segunda Guerra Mundial, 10\% da sua população era de apátridas (ARENDT, 2004, p. 313).

As declarações dos Direitos do Homem, proclamadas no fim do século XVIII, resultantes das Revoluções Americana e Francesa, forneceram a base política para o Estado moderno, cuja legitimidade deixava de fundamentar-se em motivos religiosos ou em hierarquias sociais que dividiam a população em estamentos definidos pelos seus privilégios sociais (BRITO, 2010, p. 15). A grande novidade dessas declarações é que nelas o homem tem, por sua natureza, direitos inalienáveis que não dependem de suas posições na sociedade e na política, mas, pelo contrário, precedem a elas; são direitos naturais, intrínsecos à natureza humana, e o contrato social deve garanti-los (KEVERGAN, 2001, p. 89). 
A declaração norte-americana de 1776 delibera que todos os homens são iguais por natureza e gozam de direitos inalienáveis, entre eles a vida, a liberdade e a busca da felicidade. O governo existe para garantir estes direitos e a sua legitimidade deriva do consentimento dos governados. É um direito do povo de rebelar-se contra o governo se este não obedece ao seu fim primordial de garantir os direitos naturais (BRITO, 2010, p. 15).

As grandes novidades da declaração francesa estão contidas nos seus três primeiros artigos: o primeiro reconhece, como na americana, que os homens nascem e permanecem livres e iguais em direitos; o segundo enuncia que os objetivos do contrato social, ou da associação política, é a "conservação dos direitos naturais e imprescritiveis do homem, tais como a liberdade, a propriedade, a segurança e a resistência à opressão" (HUNT, 2009, p. 225); e o terceiro afirma que o princípio da soberania reside na nação e não em ordens ou estamentos (BOBBIO, 2004, p. 90).

Por um lado, o homem passa a ser o único soberano em questões de lei e, por outro, o povo era definido como o único soberano em matéria de governo. Essa soberania não se legitimava pela graça de Deus ou do Rei, mas em nome dos direitos inalienáveis do homem.

Hannah Arendt, entretanto, apesar de reconhecer a importância histórica dos direitos humanos proclamados pelas Revoluções Americana e Francesa, critica a sua fundamentação no direito natural. Os homens não são iguais por natureza e nem o são, muito menos, em função da sociedade em que vivem. Eles tornam-se iguais no universo da política, artifício construído pelos próprios homens por meio de um contrato social, edificado no solo da pluralidade humana, e não no espaço politicamente vazio do homem no singular (ARENDT, 2004, p. 324).

A crítica de Arendt aos direitos humanos não se reduz somente à sua fundamentação na natureza humana, mas estende-se, também, à relação entre os direitos humanos e a soberania nacional. O ser humano, na sua individualidade abstrata, só assumia o seu rosto de cidadão por meio do povo ao qual pertencia. Os direitos humanos, portanto, só se configuram com a emancipação de um povo no contexto da constituição do Estado nacional. A nação, como expressão da vontade geral, se sobrepõe ao indivíduo, ser humano abstrato, e os seus direitos nela se ancoravam (ARENDT, 2004, p. 261).

Desse modo, segundo Arendt, as revoluções, em particular a francesa, subordinaram os direitos do homem à soberania nacional. "O resultado prático dessa contradição foi que, daí por diante, os direitos humanos passaram a ser protegidos e aplicados sob a forma de direitos nacionais” (ARENDT, 2004, p. 262). É a tragédia do Estado-nação moderno, que somente reconhece como cidadãos aqueles que pertencem à comunidade nacional, os únicos que podem usufruir plenamente dos direitos civis e políticos.

O termo nação, etimologicamente, vem do latim, natio, do verbo natus, nascer, identificando-se com o povo nascido em determinado território, parte essencial da trindade Estado-Povo-Território. O princípio da nacionalidade transforma-se no vínculo político entre o indivíduo e o Estado e é condição necessária para ser membro da comunidade política (LEFORT, 1991, p. 63). Este é o grande paradoxo dos direitos humanos, pois se supunha 
que, intrínsecos à natureza humana, como professavam as Revoluções Americana e Francesa, fossem independentes da nacionalidade (ARENDT, 2004, p. 326).

Quando surgem, então, na cena histórica aqueles como os apátridas, que não participam de nenhuma comunidade política, o conceito de direitos humanos perde sua eficácia. Totalmente despidos dos seus direitos, os apátridas e, muitas vezes, as minorias e os imigrantes eram uma afronta às conquistas das Revoluções Americana e Francesa.

A visão dos direitos humanos exclusivos dos nacionais suporta uma concepção do Estado-Nação que pressupõe a homogeneidade do seu povo, muitas vezes confundida com a identidade étnica, considerada um dado pré-político, anterior ao contrato social (HABERMAS, 2004, p. 159). O entendimento de homogeneidade étnica como base do Estado-nação consagra a ruptura dos direitos humanos, que passam a ser um privilégio dos nacionais e, mais radicalmente, dos nacionais de etnias semelhantes.

Os apátridas, assim como, em muitas circunstâncias, as minorias nacionais e os imigrantes, são considerados supérfluos, ou seja, pessoas cujos direitos humanos essenciais não são reconhecidos pelo Estado e, desse modo, são política e socialmente indesejáveis (BRITO, 2010, p. 18). Historicamente, abre-se a antessala de uma sociedade totalitária, na qual a geração de enormes contingentes de homens supérfluos, segregados social e politicamente, acabaria introduzindo na cena histórica a tragédia dos campos de concentração e de trabalho (ARENDT, 1990, p. 122, e 2004, p. 498).

\section{Migrações, direitos humanos e soberania nacional após a Segunda Grande Guerra}

As experiências totalitárias e a guerra levaram à ruptura radical dos direitos humanos. Clamava-se por uma resposta da comunidade internacional sem a qual o próprio conceito de humanidade estaria fortemente comprometido. A experiência da Liga das Nações, criada em 1919 pelas potências vitoriosas na Primeira Grande Guerra, não foi bem-sucedida. Seus objetivos eram supervisionar o desarmamento dos países derrotados e garantir a paz e a proteção dos direitos das minorias em suas respectivas nações. Seu fracasso pode ser compreendido pela falta de consenso entre os países hegemônicos sobre a própria concepção da organização das relações internacionais.

Predominava a ideologia da supremacia social, econômica e étnica da Europa, necessária para garantir o controle sobre o seu vasto sistema colonial gerado no período do imperialismo. A inoperância política da Liga das Nações se mostrou definitiva com a sua incapacidade de evitar a emergência das experiências totalitárias e, consequentemente, a Segunda Grande Guerra (HUNT, 2009, p. 203).

A criação da Organização das Nações Unidas, com o objetivo de superar as limitações da Liga das Nações, foi a resposta encontrada pelas grandes potências vitoriosas na Segunda Grande Guerra para impedir o ressurgimento de um novo desastre humanitário. Na Conferência de lalta, no início de 1945, os governantes dos Estados Unidos, Inglaterra e União Soviética já tinham em pauta o monitoramento dos direitos humanos nos diferentes 
países, entretanto, sobrepuseram-se na agenda da política internacional as questões referentes à delimitação das fronteiras no pós-guerra e o sistema de segurança coletivo (BELLI, 2009, p. 29).

A Carta de fundação das Nações Unidas, definida na Conferência de São Francisco, em 1945, continha no seu preâmbulo uma menção geral à necessidade de respeito universal aos direitos humanos e às liberdades essenciais sem distinção de sexo, raça, língua ou religião e, no artigo 1.3, afirmava a necessidade de cooperação internacional para a solução de diferentes problemas, entre eles, promover e encorajar o respeito aos direitos humanos (BELLI, 2009, p. 33). O grande obstáculo à política efetiva dos direitos humanos está no artigo 2.7, que resguarda a soberania dos países: "Nenhum dispositivo da presente Carta autorizará as Nações Unidas a intervirem em assuntos que dependam essencialmente da jurisdição de qualquer Estado ou obrigará os Membros a submeterem tais assuntos a uma solução, nos termos da presente Carta”. Este princípio, excepcionalmente, não se aplicava às decisões do Conselho de Segurança, no qual as grandes potências tinham poder de veto (BELLI, 2009, p. 35).

Todavia, no capítulo X, artigo 68, a Carta previa que o Conselho Econômico e Social criaria uma Comissão de Direitos Humanos, o que ocorreu em sua segunda sessão, em 1946, definindo como prioritária a elaboração de uma Carta Internacional de Direitos (BELLI, 2009, p. 35).

Em 1947, a Comissão de Direitos Humanos, dirigida pela ex-primeira dama dos Estados Unidos, Eleanor Roosevelt, iniciou seus trabalhos com o objetivo ambicioso de elaborar, além de uma declaração de princípios, um tratado com obrigações legais. Entretanto, a estrutura de poder das Nações Unidas, reflexo das condições internacionais do pós-guerra, não possibilitou ir além de uma declaração, que tinha, evidentemente, uma força moral, mas era desprovida das obrigações inerentes a um tratado (BELLI, 2009, p. 40).

No dia 10 de dezembro de 1948, foi aprovada pela Assembleia Geral das Nações Unidas a Declaração Universal dos Direitos Humanos, com o voto de 48 países, nenhum voto contra e oito abstenções: Arábia Saudita, África do Sul e os seis países do bloco soviético (HUNT, 2009, p. 206).

No seu preâmbulo, a Declaração explicita "que o reconhecimento da dignidade inerente a todos os membros da família humana e de seus direitos iguais e inalienáveis é o fundamento da liberdade, da justiça e da paz no mundo". Reconhece, também, visando o passado recente, "que o desrespeito e o desprezo pelos direitos humanos têm resultado em atos bárbaros que ofenderam a consciência da humanidade e que o advento de um mundo em que os seres humanos tenham liberdade de viver sem medo e privações foi proclamado como a aspiração mais elementar do homem comum". Portanto, é fundamental que "os direitos humanos sejam protegidos pelo estado de direito, para que o homem não seja compelido a recorrer, em última instância, à rebelião contra a tirania e a opressão" (HUNT, 2009, p. 229).

A fé reafirmada nos direitos humanos e o compromisso dos povos das Nações Unidas em respeitá-los são amenizados nas conclusões do mesmo preâmbulo quando se afirma: “A 
Assembléia Geral proclama esta Declaração Universal dos Direitos Humanos como um ideal comum a ser alcançado por todos os povos e todas as nações". Na verdade, esse conjunto de obrigações, ou ideal comum, não veio acompanhado de nenhum mecanismo que garantisse a sua efetiva implementação em cada um dos países (HUNT, 2009, p. 230).

Certamente, se estes mecanismos fossem explicitados, a Declaração não teria sido aprovada, pois a ONU não tinha capacidade política e jurídica de se sobrepor à soberania de cada um dos seus países membros, como estava bem explicitado na sua Carta. Permanecia o mesmo paradoxo, já evidenciado por Hannah Arendt, referindo-se às declarações das Revoluções Americana e Francesa: ainda que com a pretensão da universalidade, a realização efetiva, política, dos direitos humanos dependia da sua incorporação na legislação de cada país.

Não se quer dizer que a importância política da Declaração deva ser minimizada. Ela, sem dúvida, estabeleceu um novo patamar para o direito internacional, colocando no horizonte a possibilidade de o indivíduo ser considerado o seu sujeito e não os Estados-nacionais. Essa revolução no direito internacional foi extremamente dificultada pela guerra fria. A soberania dos países, nas respectivas áreas de influência dos Estados Unidos e da União Soviética, condicionada pela hegemonia das duas grandes potências, sobrepunha-se aos direitos dos indivíduos (BELLI, 2009, p. 55).

Os artigos 3ำ até o 21ํำ da Declaração referem-se aos direitos humanos considerados de primeira geração. Neles procura-se resgatar, depois das tragédias que marcaram a humanidade na primeira metade do século XX, os direitos considerados inerentes à pessoa humana constitutivos das declarações revolucionárias do final do século XVIII. São direitos individuais, ou seja, a titularidade é do individuo na sua singularidade, ainda que eles se efetivem reconhecendo o direito do outro e podem, como no caso do direito de associação, ser exercidos coletivamente (LEFORT, 1991, p. 126).

Os direitos básicos contemplados, como em 1776 e 1789, são os direitos à vida, à liberdade, à segurança pessoal, ao casamento, à privacidade e à propriedade. Consagramse, também, as liberdades de pensamento, opinião, consciência, religião, expressão, reunião, associação e participação política. A escravidão, o tráfico de escravos e a tortura são condenados, assim como são garantidas a presunção à inocência e a igualdade perante a lei. Incorpora-se, também, o pressuposto das duas declarações anteriores relativas ao poder soberano, enfatizando que a vontade do povo deve ser a vontade do governo (HUNT, 2009, p. 234).

Estes direitos de primeira geração são também chamados de direitos-liberdade, porque têm como objetivo limitar o poder do Estado, segundo as tradições contratualista e individualista que inspiraram as Declarações americana e francesa (LAFER, 2006, p. 126).

Os artigos $22^{\circ}$ ao $27^{\circ}$ referem-se aos direitos considerados de segunda geração e têm a ver com os direitos econômicos e sociais, visando garantir a participação dos cidadãos em um Estado de Bem-Estar Social. Para tanto, procuram garantir os direitos à segurança social, ao trabalho, à remuneração justa, à proteção social, à organização sindical, a férias e 
a um padrão de vida que assegure saúde e bem-estar. Os direitos à educação, cultura e ao acesso ao progresso técnico e científico são também consignados junto com a proteção à infância e à maternidade (HUNT, 2009, p. 234-235).

Os direitos de segunda geração são deveres do Estado, responsável pelo bem-estar dos indivíduos. O Estado aparece como um sujeito passivo, sendo que o verdadeiro titular do direito continua sendo o indivíduo, como nos direitos-liberdade. Os direitos de primeira geração têm como meta limitar o poder soberano do Estado e ampliar a democracia política, enquanto os de segunda geração objetivam fortalecer as atividades do Estado e ampliar a democracia social (FERRY; RENAUT, 1997, p. 22; LEFORT, 1991, p. 127).

Os três últimos artigos da Declaração propõem que a ordem social e internacional assegure que os direitos humanos possam ser plenamente realizados e que os seres humanos devem estar sujeitos apenas às restrições postas pela lei, que não podem contrariar os propósitos e princípios da ONU (HUNT, 2009, p. 236).

No que se refere à mobilidade da população, a Declaração de 1948 afirma, no artigo 13, os direitos de ir e vir e de mudança de residência dentro das fronteiras do país, mas não garante a mobilidade no plano internacional, apenas menciona o direito de retorno ao país de origem e, quando o caso, o direito ao exílio (HUNT, 2009, p. 232).

O maior avanço, sem dúvida, foi o direito à nacionalidade: ninguém pode ser destituído dela e fica garantido o direito de mudá-la, se assim o indivíduo desejar. O grave problema dos apátridas, e mesmo de algumas minorias, destituídos da sua nacionalidade e impedidos de readquirir outra, em tese, estaria resolvido. O indivíduo teria o direito, segundo a Declaração, de não ser destituído de sua nacionalidade em seu país de origem, assim como de requerer outra nacionalidade no país escolhido como destino (HUNT, 2009, p. 232).

O grande problema é que o paradoxo arendtiano entre direitos humanos e soberania não foi superado pela nova Declaração. Efetivamente, a nacionalidade, do ponto de vista político e jurídico, depende menos dos direitos dos indivíduos e mais do seu reconhecimento em cada Estado-nação. O indivíduo detém a titularidade dos seus direitos, mas a sua realização no plano internacional subordina-se à soberania de cada país, que é, de fato, o principal titular no direito público internacional.

Assim, cada Estado assegura o seu direito de legitimar e controlar, dentro das suas fronteiras, os movimentos populacionais internacionais e a concessão de nacionalidade. Ambos se constituem em um dos fundamentos da sua própria soberania. Desse modo, as decisões internacionais, como a Declaração de 1948, de fato, significam mais um ideal comum a ser alcançado, sem a força política necessária para se sobrepor à soberania de cada Estado (REIS, 2004, p. 154).

A insuficiência da Declaração de 1948 levou as Nações Unidas a elaborarem um conjunto de convenções que pudessem complementá-la. Não se pode omitir uma das respostas dada pela Assembleia Geral aos horrores da Segunda Grande Guerra, esta sim sob a forma de uma convenção, considerando o genocídio como crime sob o direito penal internacional. A Convenção para a Prevenção e a Punição do Crime de Genocídio, aprovada em 9 de dezembro 
de 1948, responsabiliza penalmente não o Estado, mas as pessoas que cometeram o crime, sejam governantes, funcionários ou particulares (BELLI, 2009, p. 38).

Quanto aos apátridas e refugiados, foi aprovada, em 1951, a Convenção de Genebra Relativa ao Status de Refugiado, tendo como objetivo a garantia ao direito de asilo. Também foram aprovadas a Convenção Relativa aos Apátridas, em 1954, e a Convenção de Prevenção de Formação de Apátridas, em 1961, com a finalidade de dar àqueles que não são considerados cidadãos nacionais acesso aos mesmos direitos dos nacionais, além de facilitar o processo de naturalização (REIS, 2004, p. 151).

As migrações internacionais com o objetivo de trabalho, que cresceram muito depois da Segunda Guerra, passaram a exigir, também, as primeiras Convenções Internacionais. Duas delas foram elaboradas pela Organização Internacional do Trabalho (OIT): a primeira em 1949, a Convenção da Imigração para o Trabalho; e a segunda em 1975, a Convenção dos Trabalhadores Imigrantes. A intenção fundamental de ambas era que os imigrantes tivessem os mesmos direitos dos trabalhadores nacionais, independentemente da nacionalidade, raça, religião ou sexo. Um bom indicador dos conflitos gerados pelas migrações internacionais no pós-guerra, apesar da necessidade fundamental da mão de obra estrangeira para suprir as necessidades da economia em expansão, foi a mudança de atitude dos países de grande imigração em relação a essas Convenções. A primeira, em 1949, teve a ratificação de 41 países e a segunda, já em 1975, de apenas 18, sendo que países de grande imigração de trabalhadores, como os Estados Unidos, França e Austrália, não ratificaram (REIS, 2004, p. 152).

O novo cenário das migrações internacionais fica mais nítido a partir dos anos 1980. Os fluxos migratórios dos países em desenvolvimento em direção àqueles mais desenvolvidos se multiplicaram, principalmente para a Comunidade Europeia, os Estados Unidos, o Canadá, o Japão e a Austrália. Dentro da própria Comunidade Europeia havia um intenso movimento populacional proveniente dos países do leste europeu. Acrescente-se que as imigrações das antigas colônias, principalmente na Europa, não só se ampliavam como já se reproduziam em diferentes gerações nascidas nos próprios países de destino.

Essa intensificação dos fluxos migratórios internacionais tem sido contemporânea de rápidas e profundas transformações na estrutura produtiva do capitalismo, com fortes repercussões sobre o mercado de trabalho (TAPINOS; DELAUNAY, 2001, p. 26). Apesar da criação de novas ocupações, requeridas pelos novos processos tecnológicos e pelas novas formas de organização do trabalho, tem havido uma enorme redução nas necessidades de mão de obra. Desse modo, os mercados de trabalho estão mais seletivos, exigindo maior treinamento educacional. Como consequência, verifica-se um aumento fantástico das taxas de desemprego, recentemente alimentadas pela forte crise econômica, gerando um excedente estrutural de força de trabalho que tem avançado, inclusive, sobre os espaços secundários do mercado de trabalho, tradicional nicho dos imigrantes (BRITO, 1995, p. 62).

A situação demográfica dos países desenvolvidos, depois de décadas de taxas de fecundidade abaixo do nível de reposição, tem gerado um aumento inédito do grau de envelhecimento da população. Este crescimento da proporção de idosos em relação à 
população economicamente ativa tem pressionado o financiamento das políticas sociais incorporadas no Welfare State, aguçando a crise fiscal do Estado. Consequentemente, têm surgido políticas restringindo muitas das ações da seguridade social e ampliando os estímulos a um mercado de trabalho mais competitivo.

As dificuldades do Welfare State e o mercado de trabalho cada vez mais competitivo estão entre as causas das políticas restritivas à entrada de imigrantes e do ambiente cada vez mais adverso para eles. Concomitantemente, tem sido notável o ressurgimento de movimentos nacionalistas, principalmente na Europa, como se o reforço da identidade nacional por meio de concepções étnicas de nacionalidade, alimentadas por ideologias raciais antigas na cultura europeia, pudesse compensar as adversidades postas pela nova realidade econômica e demográfica.

Neste contexto, as imigrações internacionais assumiram uma dimensão inusitada, expressa não só na atitude repressiva do Estado em relação aos imigrantes, mas também no aumento da sua importância na cena política. Essa politização tem duas dimensões essenciais. Uma delas refere-se aos imigrantes temporários que circulam dentro do mercado internacional de trabalho. De fato, a maioria dos imigrantes internacionais é temporária, pois a perspectiva de integração na sociedade de destino é mínima devido não só à competitividade no mercado de trabalho, mas também à quase total impossibilidade de qualquer tipo de mobilidade social ascendente. A institucionalização de diferenças sociais e culturais, que resvalam para um preconceito social e étnico, tem reforçado as adversidades aos imigrantes incentivando a temporalidade.

Entre os imigrantes temporários ainda existem os ilegais, aqueles que não possuem a documentação necessária para permanecer e trabalhar no país, cuja situação é mais grave, pois estão sujeitos à prisão e à deportação. Legais ou não, os imigrantes não têm como meta prioritária a integração na sociedade de um país desenvolvido, constituindo-se apenas como membros de um mercado de trabalho internacionalizado. Só que no capitalismo contemporâneo, ao contrário do mercado financeiro em que a livre circulação do capital é um dos seus pré-requisitos, o mercado de trabalho restringe a livre circulação da mão de obra. Ela esbarra em um dos fundamentos da soberania nacional que é o monopólio sobre a legitimidade da mobilidade internacional da população dentro do seu território. Essa é uma das dimensões essenciais da politização das migrações internacionais (REIS, 2004, p. 150).

A outra dimensão da politização tem a ver com os imigrantes não temporários e seus descendentes (ESSER, 2004, p. 1139). Aqueles que se integram à sociedade e são assimilados por ela não se constituem em problema, a não ser quando os critérios de desigualdade social incorporam as diferenças de nacionalidade ou de etnia da família de origem. O problema maior é daqueles migrantes, ou seus descendentes, provenientes de culturas e etnias diferentes, às vezes antigas colônias, que não se dispõem à assimilação pela sociedade, decididos a manter traços culturais da sociedade de origem.

No caso da Europa, particularmente, este é um tópico fundamental e relaciona-se com a questão da soberania, pois implicaria a redefinição das relações contratuais entre a 
sociedade e o Estado pautadas constitucionalmente. Com a pressão dos imigrantes e seus descendentes, a tendência tem sido de que se recrudesça a legislação, reforçando as bases sociais, culturais e étnicas que garantem a unidade da nação. As condições demográficas potencializam esse recrudescimento, já que a população de nacionais tende a diminuir em termos absolutos, enquanto a dos imigrantes e seus descendentes ainda se mantém com um crescimento positivo (COLEMAN, 2006, p. 404). Um possível rompimento da unidade social e cultural da nação tem sido compreendido como uma ameaça ao poder soberano do Estado e reforçado ideologias nacionalistas, com forte conteúdo étnico, centradas no anti-imigracionismo.

Ambas as dimensões da politização das imigrações internacionais acenam para a ruptura dos direitos humanos, na perspectiva arendtiana. Problema que se manteve historicamente desde a proclamação dos direitos humanos nas Declarações de 1776 e 1789 e que se confirmou na Declaração de 1948.

\section{Conclusões: 0 direito a ter direitos}

A Declaração das Nações Unidas não sugeria a liberdade de movimento da população colidindo com o monopólio de cada Estado de legitimar os movimentos populacionais pelas suas fronteiras. Ela avançava no direito à nacionalidade, resguardando, inclusive, o direito à sua mudança. Certamente, ela referia-se mais àqueles desnacionalizados em seus países de origem que demandavam uma nova nacionalidade em um país de destino, os apátridas. Não é o caso dos imigrantes que mantêm sua nacionalidade de origem, mas não levam consigo, dentro do mercado de trabalho internacionalizado, os direitos que tinham em seus países. Maior evidência não poderia existir de que os direitos humanos não são intrínsecos à natureza humana, pois cessam logo que o indivíduo atravessa as fronteiras da sua nação.

Despidos dos seus direitos, os imigrantes ficam à mercê da soberania exercida pelo Estado no país de destino. Na maioria das vezes, eles perdem sua cidadania plena, ou seja, o direito de pertencer a uma sociedade e a uma comunidade política. Os imigrantes são seres supérfluos, reconhecidos apenas pela sua força de trabalho, mercadoria disponível para as ocupações socialmente subalternas na hierarquia social (FREEMAN, 2004, p. 949).

A gravidade da situação dos imigrantes internacionais levou a Assembleia Geral das Nações Unidas a aprovar, em dezembro de 1990, a Convenção sobre os Direitos dos Imigrantes, com o objetivo de exigir o mesmo tratamento no trabalho para os imigrantes legais e os nacionais e o direito de apelação ao Judiciário em caso de deportação. Essa convenção só foi ratificada em março de 2003 e, mais uma vez, sem a assinatura dos principais países receptores de imigrantes (REIS, 2004, p. 152).

A importância dos direitos humanos na política internacional motivou as Nações Unidas a convocarem uma conferência específica para discuti-los, em 1993, em Viena. Dois grandes avanços merecem ser mencionados: a criação do Alto Comissariado dos Direitos Humanos; e a implementação de um Tribunal Penal Internacional para julgar os crimes contra os direitos 
humanos. Esse último só se efetivou, de fato, em 1998, com o Tratado de Roma, com o objetivo estrito de julgar os crimes de genocídio, guerra e agressão. Por princípio, sua finalidade não é julgar a conduta de países em relação aos direitos humanos, mas sim o delito de indivíduos, governantes ou não, contra o direito internacional (REIS, 2006, p. 36).

Quanto ao deslocamento das pessoas no plano internacional, a Convenção de Viena, além de confirmar a necessidade de proteção das minorias e a garantia ao direito de asilo, insiste na necessidade de proteção dos direitos humanos dos trabalhadores imigrantes, nos seus artigos 33 e 34 e, em particular, dos grupos mais vulneráveis, como as mulheres e as crianças (REIS, 2006, p. 36).

A Conferência da ONU, no Cairo, sobre População e Desenvolvimento, um ano após a de Viena, em 1994, trata da questão dos movimentos internacionais de população dividida em quatro grandes grupos: migrações internacionais e desenvolvimento; imigrantes documentados; imigrantes indocumentados; e os deslocados forçados, refugiados e solicitantes de asilo. O primeiro grupo enfatiza a dimensão positiva das migrações internacionais tanto no país de origem quanto no de destino. No caso da emigração, os governos devem atuar no sentido de intervir nas causas para que o indivíduo possa permanecer em seu país, bem como apoiar os emigrantes viabilizando a entrada das suas remessas e apoiando o seu retorno. Os imigrantes trabalhadores, documentados, segundo a Conferência, devem ter tratamento semelhante ao dos trabalhadores nacionais. Quanto aos indocumentados, reconhece-se o direito soberano do Estado de decidir sobre a sua entrada e permanência, insistindo na necessidade de se evitarem o racismo, a xenofobia, a exploração e o tráfico de trabalhadores. No caso dos deslocados forçados e solicitantes de asilo, o objetivo é combater as causas e garantir sua proteção internacional (POVOA; SPRANDEL, 2009, p. 303).

Apesar não ter sido superada a questão fundamental da sobreposição da soberania nacional sobre o direito individual, o regime internacional de direitos humanos se impõe como um condicionante importante a ser considerado na análise das políticas migratórias. Não há dúvida de que existe uma tensão entre o regime jurídico internacional que tem por sujeito a nação e um sistema de direitos humanos que tem como sujeito os indivíduos independentes de suas nacionalidades. Os Estados nacionais, ainda que possam ser vulneráveis às pressões internacionais, não se dispõem a abrir mão da sua autodeterminação, ou do seu poder soberano, no que se refere tanto ao controle da mobilidade internacional da população que passa pelo seu país, quanto ao controle sobre a concessão de nacionalidade (PASTORE, 2005, p. 349).

O contexto atual está longe de sugerir uma governança das migrações internacionais que subordine as nações ao regime dos direitos humanos individuais, embora tenha sido somada às atividades das Nações Unidas, a partir dos anos 1970, uma rede de organizações não governamentais que não pode ser desprezada na cena da política internacional, com o objetivo de zelar pelos direitos humanos, no geral, e pelos direitos dos imigrantes, em particular (REIS, 2006, p. 39). 
Todavia, não se pode desconhecer o indiscutivel esforço da ONU, e das organizações não governamentais, para proteger os direitos humanos dos imigrantes. Contudo, não se constrói um sistema internacional de direitos humanos independente da estrutura de poder que rege as relações entre as nações. O período da guerra fria acabou desdobrando a Declaração de 1948 em dois pactos aprovados pela Assembleia Geral em 1966, mas que só entraram em vigor dez anos depois. A existência de dois pactos, um sobre direitos civis e políticos e outro sobre direitos econômicos, sociais e culturais, foi resultante dos conflitos sobre prioridades entre os países ocidentais, defensores dos primeiros, e os socialistas, defensores dos segundos (BELLI, 2009, p. 46).

Mesmo nesse período de enormes dificuldades políticas internacionais, foi de grande relevância a Comissão de Direitos Humanos da ONU, abrindo brechas na inércia da bipolaridade refletida no seu Conselho de Segurança e lutando contra o racismo, o colonialismo e os regimes ditatoriais, inclusive os da América Latina (BELLI, 2009, p. 67, 71-73).

Superada a bipolaridade da guerra fria com a derrocada dos regimes socialistas articulados à União Soviética, na Conferência de Viena o sistema internacional de direitos humanos se viu ameaçado pela visão relativista dos direitos humanos defendida por muitos países asiáticos, inclusive a China, e pelos países islâmicos. Foi notável a vitória da concepção universalista dos direitos humanos contra o relativismo, que muitas vezes escondia argumentos favoráveis a alguns Estados historicamente autoritários. Um novo sopro de otimismo alimentou novas esperanças quanto ao sistema internacional de direitos humanos (BELLI, 2009, p. 98).

Contudo, ao otimismo se sucedeu uma apreensão, particularmente, quanto à atuação das Nações Unidas. A Comissão de Direitos Humanos da ONU foi substituída em 27/03/2006, 60 anos depois da sua criação, pelo Conselho de Direitos Humanos ligado diretamente à Assembleia Geral. Essa mudança fazia parte da tentativa de reforma das Nações Unidas e tinha como objetivo corrigir as ingerências políticas nas decisões da antiga Comissão (BELLI, 2009, p. 1-2). As possibilidades de êxito do novo Conselho dependem da sua capacidade de superar, efetivamente, o obstáculo que a Comissão sempre encontrou: a submissão do sistema internacional de direitos humanos aos direitos dos Estados nacionais reconhecidos pela própria Organização das Nações Unidas.

A tutela dos direitos dos imigrantes nos países mais desenvolvidos será um dos seus testes definitivos. A grande questão é que os problemas gerados pelas migrações internacionais implicam a superação dos alicerces da soberania dos Estados nacionais: os monopólios sobre o controle da mobilidade populacional no território e sobre a concessão da nacionalidade (REIS, 2004, p.155).

A proposta de Hannah Arendt para solucionar o paradoxo posto pelos apátridas, as minorias e os imigrantes internacionais seria um direito inalienável a ter direitos (ARENDT, 2004, p. 330). Não se trata de uma mera proposta filosófica, mas sim de uma nova concepção dos direitos humanos que se realiza no espaço político internacional independente dos Estados nacionais (BRITO, 2010, p. 23). Não é a ilusão totalitária de um Estado internacional 
subordinando as diferentes nações; pelo contrário, a ideia de Arendt refere-se à construção de um espaço político internacional que assegure a tutela dos direitos humanos além das soberanias nacionais, e essa é a sua grande novidade (BRITO, 2010, p. 23).

A história mostra que a tutela dos direitos humanos pelo sistema internacional implantado pelas Nações Unidas, mesmo com todos os progressos após a Segunda Grande Guerra, não assegurou o direito a ter direitos. Contudo, ele se constitui em uma nova sinalização política para a compreensão crítica das democracias liberais contemporâneas, que estabeleceram limites territoriais para o pleno exercício dos direitos humanos. O direito a ter direitos não é só a negação do totalitarismo, nas suas formas clássicas do nazismo e do stalinismo, mas é, também, a negação dos seus resíduos que ainda prevalecem nas democracias liberais resistentes a uma verdadeira tutela internacional dos direitos humanos.

\section{Referências}

ARENDT, H. Origem do totalitarismo. São Paulo: Companhia das Letras, 2004. La nature du totalitarisme. Paris: Editions Payot, 1990.

BELLI, B. A politização dos direitos humanos. São Paulo: Editora Perspectiva, 2009.

BOBBIO, N. A era dos direitos. Rio de Janeiro: Editora Campos, 2004.

BRITO, F. A ruptura dos direitos humanos na filosofia política de Hannah Arendt. Belo Horizonte: Cedeplar/UFMG, 2010 (Textos para a discussão, 402). Crescimento demográfico e migrações na transição para o trabalho assalariado. Revista Brasileira de Estudos de População, v. 21, n. 1, jan.-jun. 2004. Ensaios sobre as migrações internacionais no desenvolvimento do capitalismo. Revista Brasileira de Estudos de População, v. 12, n. 1-2, jan.-dez. 1995.

COLEMAN, D. Immigration and ethnic change in low-fertility countries; a third demographic transition. Population and Development Review, v. 32, n. 3, September 2006.

ESSER, H. Does the "new" immigration require a "new" theory of intergenerational integration? International Migration Review, v. 38, Fall 2004.

FERRY, L.; RENAUT, A. Filosofia política. De los derechos del hombre a la idea republicana. México: Fundo de Cultura Econômica, v. 3, 1997.

FOUCAULT, M. Em defesa da sociedade. São Paulo: Martins Fontes, 2005.

HABERMANS, J. A inclusão do outro: estudos de teoria política. São Paulo: Edições Loyola, 2004. HOBSBAWN, E. A era dos impérios: 1875-1914. São Paulo: Editora Paz e Terra, 2003.

HUNT, L. A invenção dos direitos humanos: uma história. São Paulo: Companhia das Letras, 2009. KEVERGAN, J. F. Os direitos humanos. Ensaios de filosofia política. São Leopoldo-RS: Editora Unisinos, 2001.

LAFER, C. A reconstrução dos direitos humanos: um dialogo com o pensamento de Hannah Arendt. São Paulo: Companhia das Letras, 2006.

LEFORT, C. Pensando o político: ensaios sobre democracia, revolução e liberdade. São Paulo: Paz e Terra, 1991. 
NABUCO, J. O abolicionismo. Interpretes do Brasil. Rio de Janeiro: Editora Nova Aguilar, 2000.

PASTORE, F. The policies for the management of international migrations from the XX to XXI century. In: GENUS, PROCEEDING OF THE INTERNATIONAL CONFERENCE: TRENDS AND PROBLEMS OF THE WORLD POPULATION IN THE XXI CENTURY. Roma, 2005

FREEMAN, G. P. Immigrant incorporation in western democracies. International Migration Review, v.3, n. 8, Fall 2004.

PÓVOA NETO, H.; SPRANDEL, M. A. População e Desenvolvimento (Cairo,1994) e a política migratória brasileira. Brasil, 15 anos após a Conferência do Cairo. Campinas: Abep-UNFPA, 2009.

READERS, G. 0 inimigo cordial: o conde Gobineau no Brasil. São Paulo: Paz e Terra, 1998.

REIS, R. R. Os direitos humanos e a política internacional. Revista de Sociologia Política, Curitiba, n. 27, p. 33-42, nov. 2006.

. Soberania, direitos humanos e migrações internacionais. Revista Brasileira de Ciências Sociais, v. 19, n. 55/junho, p. 149-164, 2004.

SKIDMORE, T. E. Preto no branco: raça e nacionalidade no pensamento brasileiro. São Paulo: Editora Paz e Terra, 1976.

TAPINOS, G.; DELAUNAY, D. Se puede hablar realmente de la globalización de los fluxos migratórios? Notas de Poblacion, Ano XXVIII, n. 73, 2001.

VIANA, O. Populações meridionais do Brasil. Interpretes do Brasil. Rio de Janeiro: Editora Nova Aguilar, 2000.

\section{Abstract}

The politicization of international migration: human rights and national sovereignty

The aim of this paper is to analyze the response of developed countries to international immigration through restrictive legislation. The cause of this reaction is not only cyclical, derived from the contemporary crisis of capitalism, as it also lies in the structural formation of the countries that attract immigrants. The basis of the political analysis undertaken here is the understanding of the paradox between the sovereignty of each country and the universalization of human rights, especially of immigrants. Following a line of thinking similar to Hanna Arendt's, the present analysis of the politicization of international migration is based on its history from the second half of the nineteenth century until the present day, emphasizing three major periods: pre-World War I, recognized as the era of imperialism, the period between the two World Wars, and the postwar period, marked especially by the Universal Declaration of Human Rights, in 1948.

Keywords: International migration. Human rights. National sovereignty.

\section{Resumen}

La politización de las migraciones internacionales: derechos humanos y soberanía nacional

El objetivo de este artículo es analizar la reacción de los países desarrollados a la inmigración internacional a través de una legislación restrictiva. Se considera que la causa de tal reacción no es exclusivamente coyuntural, derivada de la crisis contemporánea del capitalismo, sino que reside en 
la propia formación estructural de estos países receptores de inmigrantes. El fundamento del análisis político desarrollado se encuentra en la comprensión de la paradoja establecida entre la soberanía de cada uno de los países y la universalización de los derechos humanos, en especial, de los inmigrantes. Siguiendo un itinerario similar al de Hanna Arendt, el análisis de la politización de las migraciones internacionales acompañará su historia a partir de la segunda mitad del siglo XIX hasta la actualidad, enfatizando tres grandes periodos: el anterior a la Primera Guerra Mundial, reconocido como la era del imperialismo; el periodo entre las dos Grandes Guerras Mundiales; y el postguerra, contemplado, ya en su momento inicial, por la Declaración Universal de los Derechos Humanos de 1948.

Palabras clave: Migración internacional. Derechos humanos. Soberanía nacional.

Recebido para publicação em 16/05/2011

Aceito para publicação em 08/08/2011 